\title{
Analytical Models of Legislative Texts for Muslim Scholars
}

\author{
Dr. Ammar Abdullah Naseh Alwan \\ Academy of Islamic Studies, University of Malaya,50603 Kuala lumpur, Malaysia \\ Tel: 60-13-212-8550Ｅ-mail: ammar@um.edu.my \\ Prof.Dr.Mohd Yakubzulkifli Bin Mohd Yusoff \\ Academy of Islamic Studies, University of Malaya,50603 Kuala lumpur, Malaysia \\ Tel: 60-16-304-1454Ｅ-mail: zulkifliy@um.edu.my \\ Dr. Mohammad Said M Al-Hami \\ Academy of Islamic Studies, University of Malaya,50603 Kuala lumpur, Malaysia \\ Tel: 60-17-218-3347 E-mail: m.tomeei@um.edu.my
}

\begin{abstract}
The significance of the analytical models in traditional Islamic studies is that they contribute in sharpening the intellectual capacity of the students of Islamic studies. Research literature in Islamic studies has descriptive side predominantly; the information is gathered and compiled and rarely analyzed properly. This weakness is because of not having use of analytical approach in the field of traditional Islamic studies and this lacking stimulates researchers to exert efforts to set bases that assist students in analyzing shar'iyah texts. This research will hopefully be the first step for drawing an analytical approach within the field of traditional Islamic studies.
\end{abstract}

Keywords: Analytical models, Legislative texts, Islamic texts, Islamic methodology

\section{Introduction}

There seems to be lack of previous studies that could provide an independent analytical approach in the field of fiqh (Islamic Jurisprudence) and its usul (Principles of Islamic Jurisprudence) except some articles and rare researches which I have mentioned and discussed in this study, such as Abdelrahman Al-Halali's article "azmat al-bahth al-ilmi fi al-jam 'at al-islamiya" (The Crisis of Scientific Research in Islamic Universities).

Scientific research in post-graduate studies, especially one of its components is textual tahqiq (verification), it has contributed in establishing the approach that students are to follow in textual verification since there are influential scholars who have contributed to this field. These scholars have established an approach for textual verification similar to the one of Muhaqqiin (verifiers). Sheikh - Abdussalam Haroun (b. 1909 A.D, d. 1988 A.D) in his book, "Tahqia An-Nusous wa Nashriha" (Textual Verification and its Publishing) is considered the first Arabic book of its kind that demonstrates its approaches and solves its set problems (Al-Amin, Abdelkarim and Ibrahim, Zahida, 1970, p. 251). Textual verification as an approach is not yet well integrated because it requires providing an analytical study for the verified material or text. There seems to be no effective analytical approach -partial or complete - that gradually improves the reasoning ability of students in analyzing scientific material in their subjects of specialization. Of course, there is a scientific approach which lays out steps for writing scientific researches but it is not appropriate for analyzing the scientific material. Some existing analytical approaches are based on Western framework and conception of analysis. There are some Arab analytical works, such as Ibn Alqayym's (b. 691 A.H, d. 751 A.H) work, "Manhajiyyat Al-Emam Ash-Shafi'i ( Abu-sulayman, Abdelwahhab Ibrahim, 1999).

This research endeavors to lay out primary steps in establishing an analytical approach for Islamic studies. The present paper will examine several problems and themes associated with an analytical approach in Islamic studies, including: (1) The significance of the analytical approach in Islamic studies, (2) Qur'anic and prophetic approach urges Muslims to develop an analytical mentality, (3) contrast between Whitehead and Shatibi in regards to acquisition stages that lead to the analytical stage, (4) features of the analysis developed by Ibn Khaldoun and Muhammed Abu Zahra, (5) analytical applications in the Islamic sciences, and (6) essential pedagogical suggestions for establishing an analytical approach in curricula and syllabi.

\section{Qur'anic Approach in Developing Analytical Reasoning Ability}

The Qur'an is the primary source of Islamic knowledge and for developing that knowledge whoever studies Qur'anic verses will find that they urge analysis of events, especially historical ones, and also the need to derive directly Allah's 
sunnan (rules) that he created for the universe. The word (His ways of doing things) appears in the Qur'an many times and Allah asks believers to know His sunnan and to take them into consideration in history and sociology. He also wishes for mu'minin (believers) not to contradict these sunnan if they have istikhlaf (vice regency) in Allah's dominion. Ibn Khaldoun had a great unprecedented idea to establish a firm foundation of sociology and history based on Qur'anic verses that urge believers to analyze Allah's unchangeable, immutable and eternal sunnan, no matter whether or not countries and persons change. Thus, knowing Allah's sunnan can only be through an analytical approach that links events together to discern a divine law in history and sociology.

The Qur'anic approach has not restricted or limited analytical ability to educate Muslims through tracing Allah's sunnan in history and sociology. Moreover, it also urges Muslims to use an analytical approach effectively in uncovering a crime by following clues. For example, about Al-Aziz, Qur'an states: "If his shirt is rent from front, she speaks the truth and he is one of the liars: And if his shirt is rent from behind, she tells a lie and he is one of the truthful (Quran, 12:27-28)." The Qur'anic approach deals with incidents of history in a manner that is brief; it seeks not to elaborate on all the details of the story but to mention merely what is necessary. Therefore, the aim of mentioning Al-Aziz saying is to guide Muslims to the truth by analyzing the clues of a crime and its circumstances.

\section{Prophetic Approach in Developing Analytical Ability}

The prophetic approach is integral to the Qur'an and its scientific epistemology. They are inseparably linked to each other in developing analytical ability among believers. Prophet Muhammad (Allah's blessing and peace be upon him) used to stimulate and invoke analytical ability of his companions, as exemplified in the discourse of Ibn Omar (May Allah be pleased with him): The Prophet (Allah's blessings and peace be upon him) said, "Amongst the trees, there is a tree, the leaves of which do not fall and it is like a Muslim. Tell me the name of that tree?" Everybody started thinking about the trees of the desert areas. And, Omar Says, I thought of the date-palm tree but felt too shy to answer. The others then asked, "Please inform us what is that tree, O Allah's Apostle?" He replied, "It is the date-palm tree (Sahih Bukhari, Book3)." The Prophet wanted his companions to analyze similarities between a believer and a tree and to look among all kinds of trees to find the one which is similar to a believer. The Prophet gave them the main trait that is its leaves do not fall as a key clue.

The analytical approach is more essential today than at any other time because a researcher's work has multiple dimensions and aspects. Gathering information without analysis should not be rewarded with an advanced graduate degree since it is presupposed that a postgraduate student should have the capacity to analyze in depth. On the other hand, electronic information gathering has become accessible so that a person can gather a huge amount of scientific material and countless references just by clicking a key on his computer. Consequently, gathering information without analyzing or criticism should be unacceptable in contemporary scientific research.

\section{Comparing Imam Shatibi and Alfred North Whitehead Regarding the Stages of the Acquisition of Scientific Knowledge}

Reaching an analytical stage for those who seek knowledge requires that their thinking (cognition) should pass through several pre-stages in order to reach the stage of sound scientific analysis. These stages discussed by Whitehead (b. 1861 A.D, d. 1947 A.D) were clarified by Imam Shatibi (d. 790 A.H) but , of course, by using different words. Both of them agree that achieving scientific knowledge is a gradual progressive process which starts with a receptive, memorizing stage which moves on to a stage of complex rules, coming finally to the stage of comprehensive overview which is the analytical stage.

Comparing the stages proposed by Whitehead and Shatibi, the closeness in those stages moving toward sound scientific analysis is striking. In regard to the first "primary stage", Whitehead argues that the child learns by his senses. Thus, the first learning stage is likely to be similar to the random acquisition that starts with child since his birth. Shatibi states that during this stage a person is merely memorizing and receiving knowledge about the final aims of shari'a, which is the general basis for analyzing shari'a sciences. It is incoherent, inconsistent and it has no rules like the following stage. As a result, knowledge seekers or students at this stage could not know these maqasid (the objectives of Islamic law fiqh in-depth) organized and ordered without a teacher to lead him (Ash-Shatibi, Ibrahim Bin Mousa, (nd), pp. 4225) .

The second stage, according to Whitehead, is the stage of complex rules for what one has learnt in the first stage. It is in this stage that one starts to recognize features and appearances in which the scientific analytical stage begins. The ability to establish and formulate rules means a capability in analyzing information and classification working out rules for every set of information. In this stage, according to Shatibi, the knowledge seeker can recognize some of Islamic legal laws maqasid. This means that the ability of analyzing Islamic legal laws has begun to appear and develop, but is still limited and yet to reach the last stage of a comprehensive analytical overview of the shari'a sciences. 
Whitehead saw this final stage as associated with tertiary education. The stage of formulating rules has deepened in shari'a sciences it leads on to precise analysis. Gradual progression in the acquisition stage of scientific knowledge, previously mentioned, is necessity for students in the Islamic sciences at all educational levels, aiming to reach the analytical approach at the end.

Therefore, most of theses and dissertations in the field of Islamic research which are a result of different educational stages need to be revised. Abdulrahman Al-Halali notes: "whoever looks over thousands of theses and dissertations in different universities sees a gathering together, classification and re-production of information presented as a scientific investigation, but most of them do not include tackling an argument or answering a research question or solving a problem. Furthermore, there is a separation between their topic and the era which is dealt with, no consideration for the time at which the research is carried out. Most conclusions reached are descriptive rather than analytical, and in a sense historical, looking at the picture of some past state of knowledge.

Moreover, titles of subjects and the way they are registered reveals what universities suffer from. For example, in many Islamic universities, there is no research plan that directs and integrates researches. If there is one, it will be merely formal and likely not with much implementation in concrete practice, especially in shari'a subjects. Solid research should be of high quality and contribute an essential contribution and genuine knowledge in its field. Yet the researches currently submitted in Islamic studies tends in our view to distort and trivialize Islamic turath (intellectual heritage, tradition), some of which at its time contemporary and very much up-to-date then.

Studies described as "scientific research" did not succeed in presenting the new material or preserve Islamic turath. It is not yet presented in a proper way that does not overlook the concept of amanah (trust) required in the description of scientific knowledge. On the contrary, sect, school, and selectivity bias mark much current scientific research, and the demand is often for new knowledge. Yet the new is always relative because knowledge is accumulative and integrated and the more controversial the subject, the better its results are if it is dealt with seriously. However, such seriousness does not mean breadth and addition of ever more, but rather depth of understanding, analyzing, and criticizing issues (Al-Multaqa Lilebda' Al-Fikri, 2005, April 9) .

\section{Analytical Approach in Scientific Research Needs Detailed Indexes}

A core problem in Islamic studies is that scientific research steps in scientific research have remained almost the same for half a century and we can note scant if any progress despite the different approaches, analytical, applied, and textual. Indexes written by students for theses and dissertations such as references, Qur'an verses and Hadith have become traditional in the discipline. It is vital that those who write an analytical study should make additional indexes because these support his conclusion and results. For instance, I was a consultant discussant for a study where a researcher combined fiqh and mutakalimin (philosophical school). Thesis indexes of subjects, verses and Hadith remain common and traditional. Researchers should be advised to supplement this by other indexes for usuli issues from figh scholars and the mutakalimin school so that discussants will be better able to analyze the viewpoint of the researcher.

\section{Analysis By Amr Bin Al'as For Hadith}

Mustaurid al-Qurashi reported in Sahih Muslim: Amr bin Al'as (d. 44 A.H) said: I heard Allah's Messenger (may peace be upon him) as saying:

The Last Hour would come (when) the Romans would form a majority amongst people. 'Amr said to him (Mustaurid Qurashi): See what you are saying? He said: I say what I heard from Allah's Messenger (May peace be upon him). Thereupon he said: If you say that, it is a fact for they have four qualities. They have the patience to undergo a trial and immediately regain their composure after trouble and attack again after flight. They (have the quality) of being good to the destitute and the orphans, to the weak and, fourth, they resist the oppression of kings.

The analytical sense that Amr, who was representative/ ambassador to Quraish saw was that Romans have qualities that make them a majority amongst people, including (1) the patience to undergo a trial; (2) they immediately regain their composure after trouble and attack again after flight; (3) they are kind to the destitute orphans and, the weak; (4) they resist the oppression of kings.

The real factor underlying the European renaissance today is the possession of precisely these qualities. Europe emerged from the $20^{\text {th }}$ century and its wars stronger, and Europeans today have greater resistance to the oppression of their kings because their democratic aim in Europe and America was to prevent oppression by kings and presidents. We can also see their present progress in human rights and charity associations.

\section{Ibn Taymiya's Analysis of The So-Called Jews' Book}

Ibn Taymiya (b. 661 A.H, d. 728 A.H) (Sheikh of Islam) possessed a courageous spirit as well as vast and deep knowledge. A remarkable Islamic thinker, Abu Al-Hassan An-Nadwi, (May Allah have mercy upon him), author of 
"Al-hafith Ahmed bin Taymiya", comments on "attabahur alilmi waljam'ya": "Ibn Taymiya possessed a deep and comprehensive knowledge in Islamic sciences and topics in his time due to his talented memory, rare cleverness and taste for scientific knowledge." The prominent scholar Ibn Daqiq met Ibn Taymiya in Egypt and says: "when I met him, I saw a man who is brilliant in various kinds of knowledge and sciences. He takes and leaves what he needs of these sciences."'(Al-Nadwi, Abu Al-Hassan Ali, 1975, p. 121)

An example of Ibn Taymiya's analytical capability was when asked about an alleged book of the Jews in which Muhammad rescinded the Khaybir Jews the payment of jizya (protection money paid to Muslims) . His prominent student noted: "as there were people in some countries who do not know sunna and its scholars, a group of them had an alleged book where it says: "Prophet said there was no payment of jizya tax for Khaybar Jews, and there are witnesses of Ali Bin Abi Talib, Sa'd Bin Mu'az and other groups of companions (May Allah be pleased with them)." Then, who possessed no knowledge of the Prophet's sunna were deceived and believed this book untill Ibn Taymiya was asked for help in applying and implementing what is within. He thoroughly presented and explained ten proofs that show its ingenuity:

First, there is a testimony of Sa'd Bin Mu'az who died before the Khaybir battle.

Next, the prophet rescinded kalaf and sakhr taxes and this is impossible because in his time there were no such taxes; they were imposed only by oppressive kings and they kept on taking them.

Other proofs: nobody of scholars in different fields mentioned this book, such as scholars of maghazi (military expeditions), siyar (biographies), Hadith, sunna, fiqh, fatwa and tafsir. Moreover, they did not dare to spread this book in Salaf (the predecessors) time because they would have easily discovered that it is fabricated. After that time, circumstances such as fitna (discord or upheaval) and ignorance in sunna were prevailed, and some said: Allah and his messenger paved the way for them to spread it but scholars revealed that it is full of lies ( $\mathrm{Al}_{\text {-Jawziya, Abu Abdullah Muhammad Bin }}$ Abi Bakir Ibn Al-Qayim, 1986, vol. 3, p. 137).

\section{Islamic Scientific- Method Led To Ibn Khaldoun}

Ibn Khaldoun, the father of analysis in history and sociology, was the product over time of an Islamic analytical mentality in the shari'a sciences. Ibn Khaldoun was neither brilliant nor a sheikh in science, he was only a shari'a judge. Ibn Khaldoun benefited a lot from Jarh wa Tadeel science - a method, established by Hadith scholarship, dealing with criticism of Hadith narrators to distinguish between sahih (authentic) and zaeef (weak). Ibn Khaldoun criticized historians who are not committed to the muhadithin approach in accepting and rejecting new views, and they justify this by saying that such news notions do not go into the judgment of halal (permited, licit) or haram (prohibited, illicit) issue. Furthermore, he criticized several interpreters (mufasirin) who relied on Jews in interpreting some verses without verification.

\section{Link and Balance among Shari'a Sciences}

It is clear that shari'a sciences: tafsir, hadith, fiqh, usul (principles of jurisprudence and juridical source methodology) and Arabic language, serve to build a sound understanding of texts that keeps its distance from either of the two extremes of - excess and neglect (ifrat and tafrit). Whenever a knowledge seeker deepens knowledge in one field and neglects others, then he would have an excess in the view of the shari'a sciences. This is clearly the case for Qur'an interpreters who just gather and transmit information without having the necessary knowledge in fiqh, usul al fiqh or realization of the maqasid.

\section{An applied model in fiqh analysis}

The significance of the analytical approach is clearly highlighted and shown in many aspects such as: knowing how to deduce reasons and causes of differences in results of the same scientific material; for example, cognitive ability and skill of student or knowledge seeker in analyzing issues and matters that differed in Shafi'i's (b. 150 A.H, d. 204 A.H) old and new mathhab (school of fiqh). When Bijirmi tabulated the total number of issues where Shafi'i has a difference of opinion in his old and new mathhab, he found 22 and here are examples:

it is not obligatory (wajib) to keep away from najasa (impurity) in stagnant water; touching or shaking hands with a non-Mahram woman invalidates or breaks wudu; tahara (purity) of running water as long as it does not change; it is not enough to (istinja) just using a stone if the urine -filth spreads; to expedite isha (evening prayer); maghrib prayer time extends to five raqat; not reading sura in last two raqa'at; makruh' (not likeable) of nail clipping of dead; (9) not considering of nisab [minimum value] for zakat rikaz (all items mined out of the earth including valuables that people have buried and left, natural resources...); cutting or shaving the hair of the head within the haram if afflicted by illness which prevented him from continuing; tahrim (forbidding) of eating dead animal's skin after dyeing; had (a fixed punishment for certain crimes) as a must when held; stipulated in mahram (person related to another within the forbidden degrees) by mulk alyamin (those whom your right hands possess (maidens); 
accepting testimony of two witnesses of not near relatives rather than ones of two near relatives; a fine for witnesses of money if they returned; and rejecting of the two bayyina (The Clear Proof) when they contradict. (as cited in Muhammad Abu Zahra, 1997, p. 322)

\section{Analysis of Issues Where Shafi'i Has a Difference of Opinion in His Old and New Mathhab}

I find most issues where Imam Shafi'i has a difference of opinion in his old and new mathhab do not contain texts from Qur'an or sunna. The difference goes back to either a difference in time, place, tradition, or in the geographic nature of Egypt and Iraq. The Nile in Egypt, for example, is likely to have more tahara (purity) as running water than Iraqi rivers because it has more abundant water. Also, regarding difference in geography, it does not suffice just using a stone if the urine contamination spreads due to stones in Baghdad; they might be harder compared to agriculturally soft - stone in Egypt.

Shafi'I's opinion not to consider nisab [minimum value] for zakat rikaz (all items mined out of the earth including valuables that people have buried and left, natural resources ...) goes back to the reason that in connection with many ancient treasures in Egypt and today there are still Egyptian families for which ancient treasures are their only source of living, despite government prohibitions. Shafi'i's opinion might have changed in Egypt after what he had seen the big number of treasures and depending on them as a source of living; thus, he thought the condition of nisab might "put zaka out of action" especially if we know that prophetic Hadith about zakat kunouz (treasures) does not define the quantity of nisab.

Abu Huraira said: "Allah's Apostle said that, "There is no compensation for one killed or wounded by an animal or by falling in a well, or because of working in mines; but khumus (one-fifth) is compulsory on rikaz." ' ${ }_{\mathrm{AL}-\mathrm{Bukhari} \text {, Abu }}$

Abdullah Muhammad Bin Ismail Al-Ja'fi, 1987, p. 545)

The same is said referring to extending time of maghrib prayer by five raqat that Shafi'i might gave time limit due to shortness of time between maghrib and isha prayers in Iraq while in Egypt it might extend to more than five raqat, thus he did not give time limit. As follows, Shafi'i opinion to expedite isha (evening prayer) because time difference between maghrib and isha might be longer in one of the four seasons in Egypt, because delaying time of isha prayer might cause difficulty to such a country that its people who work in agriculture and farmers have to work very early in the morning before returning exhausted in the evening.

As for nail clipping of dead, the Hanbali school of figh followers consider it is mustahab (acceptable) as a Juridical inference of it is mustahab for those alive" (Al-Maqdisi, Ibn Qudama, 1998, p. 353.). Imam Shafi'i's abandonment of istihbab (acceptability) of nail clipping of the dead in Egypt may be because it seems similar to one of ancient Egyptian notions of preserving bodies by embalmment or nail clipping of dead might be one of ancient Egyptian traditions that could have continued on into the Islamic society.

Regarding a fine for witnesses if they changed their talk, this is from Imam Shafi'i fiqh (May Allah have mercy upon him) who was well aware of his society's social illnesses. A mujtahid or a mufti as a physician in a society who then sees a kind of illness spreading will take strict measures precaution to halt and prevent this, and will think of the most suitable ijtihad in the face of social illness.

Imam Shafi'i might saw perjury as something common in Islamic society, but tried to halt this. If people did not fear Allah so as to stop perjuries, monetary fines would assist in doing that.

\section{Weak Analysis in Shari'a Sciences}

Weak analysis in the shari'a sciences results from a failure to understand the philosophy of Islamic legislation, and numerous books in Islamic legislation history discuss the historical side without analyzing the jurisprudence of Islamic fiqh. This philosophy of legislation is not only significant for clarifying ahqam at-tashri' (rules of Islamic law) but also for elucidation elements of Islamic thought derived from them.

In my view, every shari'a subject should contain at least one element of analytical material. Studying fiqh mutoun (the condensed texts of the contents of disciplines) is enough in preliminary stages but not in advanced stages. Consequently, fiqh books that help in developing analytical capability in fiqh material are a necessity, for example, in studying Al-Furouq's Al-Imam Al-Qirafi.(d.h.a682)

\section{Aspects of the Analytical Approach of Imam Muhammad Abu Zahra}

Imam Muhammad Abu Zahra is a perfect model for an analytical thinker who combines accuracy of information with its probing analysis. His approach (May Allah have mercy upon him) was not to elaborate in gathering well-known material -he termed that the "foreigners' approach," because it does not benefit the researcher who is capable of deducing shari'a sciences

He argues: "we have found sublime scholars before and after who were keen that anyone who reads what they wrote 
feels the great effort they have exerted." This is shown by mentioning many manuscripts or printed references for one matter or khabar wahid (single reports of news) although the khabar is already in itself famous, verified and one reference is more than enough. They have this approach from firinja (foreigners) who had an interest in Islamic studies, and the reason behind their use of this approach is their actual ignorance of sound deduction in Islamic studies, a field they are strangers to.

Our young writers followed this weak approach while writing, they thought that the more they mention references, the more it appears that they comprehend the new research system and that they are reformers and his writings have reached the ultimate goal or the final purpose!". Abu Zahra gives an example of those in fiqh science: "we have found that whoever gives many transcriptions or other references for each fiqh example which is already mentioned in well-known books which are more reliable than transcriptions. The mentioning of an example a lot in books purifies although the example itself might not be in its right place." (Abu Zahr, Muhammad, 1997, p. 7)

Abu Zahra states his approach: "we did not inflict hardship on ourselves; although we focus on referring each matter to its source, we do not put several references unless it is a strange idea. In doing so, we try to make it clearer to the reader's mind and not to come to his mind that we base our sayings on matters of gharib (strange), shaz (unfamiliar, unaccepted, or different than the known)." ( Abu Zahr, Muhammad, 1997, p.8.)

\section{Thoughts on an Analytical Model: Exaggeration in Mentioning Characters' Virtues}

Imam Muhammad Abu Zahra analyzed causes of this: "Since books on virtues of Abu Hanifa and Shafi'i were full of exaggeration in describing their virtues, they are full of defamation to others mentioned in these books on the one hand, while this is almost not found in Malikya books on the other hand. So, I said this was exaggeration in describing his virtues. The answer for this is that the debate occurred in the fourth century and after, in Iraq and all Oriental countries, and in different eras among Shafis and Hanafis - not Malikis. Those debates with disagreement left a heavy fire and criticism that resulted in biased writings containing exaggerations in of both praise and negative critique. As for the Malikya (Maliki School of fiqh) followers spread in Andalusia, Morocco, North Africa and the Shafi'i school of fiqh followers in Egypt and many other countries -they did not rush in praising a liar or defending him; thus, they were safe from the latter and did not drown deeper in the former." (Abu Zahr, Muhammad, 1997, pp. 12-13)

\section{Ibn Khaldoun's Approach and Analysis for the Practice of the People of Medina}

Inspired by the Islamic approach, Ibn Khaldoun's analytical approach accepts or rejects news and narrations according to the Islamic approach, but he had one extra condition for accepting historical news, where narrators have excessive flexibility (tasahul) in narrating, because this news are not categorized as halal or haram. This condition is that they do not contradict conditions of human "imran" (development). In my view, Ibn Khaldoun's approach is derived from Allah's sunnan mentioned in the Qur'an which are not vulnerable to change according to the change of time and place, since there are no miracles or extraordinary events anymore." (Ibn Khaldoun, 2003, p.35). Moreover, the birth or collapse of countries runs by one sunna that does not change according to the change of persons or means and methods.

The significance of analytical approach has a distinctive feature of bringing different sayings close; hence it clarifies the real picture of what is disagreement about. An example of this analysis is in Ibn Khaldoun's analysis of the practice of the people of Medina, the brilliant analytical mind of Ibn Khaldoun reached an analysis of their practice according to Islamic shari' $a$ which made different schools (mathahib) agreed on. Ibn Khaldoun explained the term 'the practice of the people of Medina' by stating that everyone who understands that Imam Malik when using such term means it is equal to Umma ijma (consensus of opinion) is mistaken because he refers to people of Madina as a part of Umma and their views are not considered umma ijma.

The practice of the people of Medina is distinguished from other Islamic cities that experienced the practice of tashri's (Islamic law and legislation). On this, Ibn Khaldoun says: the practice of the people of Medina is an extra legal source for rules which others have because the people of Medina see that the direct practice of their predecessors in what they do or don't do is essential thing for their religion. They follow the contemporaneous generation which was in touch with the practice of the Prophet. For Imam Malik, this appears similar to a legal source for shari'a usul. Many thought that this is case of ijma (consensus of opinion) and rejected it because ijma evidence or proof is not confined to the people of Madina but includes all the umma. And one should be aware that ijma is an agreement on religious matters after ijtihad, and Malik (May Allah have mercy on him) did not consider the practice of the people of Madina in this sense, but looked at it from the angle that they were the generation that witnessed the practice of companions and Prophet and this makes their practice as the one of umma ijma.

The matter of agreement of ahl ijma as a result of ijtihad in evidences and mujtahidiin agreement on what he did or left based on seeing the practice of predecessors, if mentioned in the chapter of what the Prophet did (fi'l) and what 
he silently approved (taqrir) or in the chapter of issues in which the scholars have disagreed [mukhtalaf fiha] like companion's mathhab, previously revealed laws (shar' man qablana) or al-Istishab (legal presumption) this would be a more suitable place for mentioning it." (Ibn Khaldoun, 2003, p.35)

Look -May Allah has mercy upon you- how he reached his legal source - the practice of the people of Madina by a large degree of agreement and approval among Islamic schools of law (mathahib) by his analysis of this matter.

Ibn Khaldoun argued that putting the matter of the practice of the people of Madina in the ijma chapter was a reason for disagreement among usuleen as to whether to accept or reject it. And if it was put in what the Prophet (Allah's blessings and peace be upon him) did, then all scholars of umma would accept the malikia school's viewpoint.

\section{Essential Suggestions for Establishing a Pedagogical Analytical Approach in Curricula and Syllabi}

Reconsidering choosing turath references according to the analytical scientific approach: in spite of the fact that turath books are many and various, we find some depend on gathering scientific information and not on any analytical mentality. Nevertheless, there are books that have this genius, with a brilliant analytical edge, but the scientific dilemma is choosing references and curricula in universities which have one distinctive feature, namely the quoted, transmitted content. Let me clarify this by examples:

\section{Highly influential turath books in usul - alfiq (principles of Islamic law, fiqh)}

Why is "Jam'u aljawame" a chosen book for Al-Azher University? This book has one distinctive feature of other books as well, which is gathering information, though it is hard to understand. (Al-Khudari, Muhammad Beik, 1965, p.10.) To my mind, it is strange to choose this book and neglect others.

\subsection{Ar-Risala}

This is the first book in 'ilm al-usul' (the Science of Principles) for the founder of this science - Al-Imam Ash-Shafi'i. It can be accompanied by Abdelhamid Abu Sulayman's "Manhajiat alimam ash-shfi' I" to understand Al-Imam Ash-Shafi'i approach "manhaj"

\subsection{Juini's books of Ghiyathi}

Allah bestowed upon Al-Imam Al-Juini an analytical mind. He (May Allah have mercy upon him) has the approach of viewing things by looking at generalities and not partialities. Thus, he aimed at establishing general rules about figh to benefit from the branches of jurisprudence that have disappeared.

\subsection{Al-Muwafaqat}

Whether it is a golden or dark age, great analytical minds appear and exist. Imam Shatibi lived in the last years of Andalusia. In the introduction to Muwafaqat introduction, Shatibi (May Allah's mercy be upon him) talked about the reason for writing this book: "to help you, my faithful friend, progressing down the path, explaining meanings of alwifaq (reconciliation) and tawfiq (harmonization): and not to be the only essential reference in verifying all that occurs to your mind of concepts and validations because it is one of the sciences that people argue about. There is no doubt that he makes things easy for you to understand and helps you in perfecting and mastering shari' $a$ knowledge."

(Ash-Shatibi, Ibrahim Bin Mousa, (nd), introduction, p. 1)

Shatibi (May Allah's mercy be upon him) took a path in writing the book that was different from that of contemporary scholars who were concerned with gathering principles of jurisprudence, rulings and texts. Their writings were aimed at gathering together and not at understanding; consequently, these writings become a source of disagreement. That was unlike Shatibi's (May Allah's mercy be upon him) approach, who wanted his book to be a contribution to the progress of scientific knowledge and enhancement in understanding and analyzing shari'a sciences.

\section{Importance of analytical study of turath}

As far as I know, there is no analytical study on the introductions of turath books. But such study in essential to appreciate such books.

Analytical thinking is underpinned by umma thawabit (unchanged principles) and not imported from the West. Establishing analytical thinking does not mean changing Umma thawabit (fixed, unchangeable principles) into usul (principles) of religion. Thus, we reject Western analytical thinking which does not believe in thawabit because they do not have them and they try to export to us their way of analytical thinking out of a grudge against Islam. They do this through Muslims who have unsound ideas and misconceptions and are disloyal to Islam like Zeid Abu An-Nasir in his "al-khitab wat ta'weel", where he states: "Importing approaches has been implemented over many decades and it has neither succeeded to establish scientific society nor to create an atmosphere for scientific thinking. In my view, the reason for this is that we see the West is superior only in the fields of technology and science and we do not see such superiority in the spiritual fields: knowledge, philosophy, culture and arts. ... The producer of science 
and technology is the person who has been taught since childhood to ask questions, think of different possibilities, have willingness to give up a conviction if it appears to him that it is not concise and most importantly not to accept the common opinions without criticizing or checking. It is the approach of doubt and reconsidering and not the approach of blind faith, false belief, obedience and following others." (Al-khitab wa ta'weel, p. 239.)

As we can see Nasr Abu Zeid asserts the image of the superior west over our culture and civilization and wants us to be followers.

\section{Conclusions}

- $\quad$ Some texts of Qur'an and Hadith encourage Muslim analytical thinking of Muslims.

- There is a close affinity between Shatibi and Whitehead in their theory regarding the acquisition of stages of scientific knowledge.

- Deepening and sharpening scientific material promotes a unique analytical skill by which to distinguish between genuine and counterfeit material.

- Ibn Khaldoun's approach in analyzing and refuting false or illogical narrations is related to the Islamic approach in accepting and rejecting narrations.

- $\quad$ There must be an analytical course as a subject in postgraduate studies in every curriculum of shari'a.

\section{References}

Al-Amiin, Abdelkarim \& Ibrahim, Zahida. (1970). daliil al-maraji' al-arabia. Shafeeq Press.

Abu-sulayman, Abdelwahhab Ibrahim (1999). manhajiaht al-Imam Bin Edris Ash-Shafi'i in alfiqh wa usuluh. Dar Ibn Hazm.

Ash-Shatibi, Ibrahim Bin Mousa (nd). almuwafaqat . Dar al-Ma'rifa, Beirut, Lebanon.

Al-Multaqa Lilebda' Al-Fikri. (2005, April 9)

Al-Khudari, Muhammad Beik. (1965). Usul Al-Fiqh. Al-Maktaba At-Tijariya, Egypt, 5th ed.

$\mathrm{Al}$ - khitab wa ta'weel, published by Morocco Cultural Center, p. 239.

Al-Nadwi, Abu Al-Hassan Ali. (1975). Al-Hafith Ibn Taymiya. Dar Al-Qalam-Kuwait.

Al-Jawziya, Abu Abdullah Muhammad Bin Abi Bakir Ibn Al-Qayim. (1986). Zad al-mi'ad fi khair al-ebad. vol. 3. Al-Manar Al-Eslamiya library: Beirut.

AL-Bukhari, Abu Abdullah Muhammad Bin Ismail Al-Ja'fi (1987). Al-Jame’ Assahih Al-Mukhtaser. Dar Ibn Kathir, 3rd ed., vol. 2.

Al-Maqdisi, Ibn Qudama. (1998). Al-Kafi fi Fiqh Al-Imam Ahmed Bin Hanbal. Dar Al-Fiqr, Damascus.

Abu Zahr, Muhammad. (1997). al-Imam Malik hayatuh wa asruh - arauh wa fiqhu. Dar Al-Fiqr Al-Arabi, 3rd edition. Ibn Khaldoun. (2003). Muqadima. Darwish Al-Juwaydi. Al-Asriya library- sayda -Beirut.

Muhammad Abu Zahra. (1997). Ash-Shafi'i Hayatuh wa Asruh-Ara'uh wa Fiqhu. Dar Al-Fikr Al-Arabi, Cairo, 3rd edition. 